\title{
Influence of Alternative Irrigation Applied Water on Water Productivity of Faba Bean (Vicia faba L.)
}

\author{
Mona A.M.EL-Mansoury 1
}

\begin{abstract}
A field experiment was conducted at Sakha Agricultural Research Station Farm, Kafr El-Sheikh Governorate. The site is located at middle North of Nile Delta with $30^{\circ}-57^{\prime} \mathrm{N}$ latitude, $31^{\circ}-07^{\prime} \mathrm{E}$ longitude and altitude of about 6 meters above mean sea level, during the two growing seasons $2013 / 2014$ and $2014 / 2015$ to study the conjunction use of rainfall with irrigation on water productivity (WP) of faba bean. Irrigation treatments were; treatment A (rainfall i.e. given only the sowing irrigation and left to rainfall during the growing season (control), treatment $B$ (given one irrigation following the sowing one), treatment $C$ (given two irrigations after the sowing watering) and treatment $D$ (given three irrigations following the sowing irrigation traditional irrigation) for faba bean cv. Giza 843 in a complete randomized design with three replications. The highest average values of water applied and consumptive use were $465 \mathrm{~mm}$ and 442 $\mathrm{mm}$ under treatment $D$ in the two growing seasons, respectively. The contribution percentages of rainfall to water applied (Wa) were $36.4 \%$ and $55.8 \%$ for treatments $D$ and $A$, respectively. Given only sowing irrigation (rainfall treatment) produced about $70 \%$ from that received 3 irrigations following the sowing one. To get nearly maximum yield, only two irrigations after the planting watering could be applied with saving water $206.5 \mathrm{~m}^{3}$ fed $^{-1}$ or $10.6 \%$. On the other hand, the highest mean values of water productively (WP) and productivity of water applied (PWa) were recorded under treatment $B$ in the two seasons and the values were 1.23 and $1.12 \mathrm{~kg} \mathrm{~m}^{-}$ 3 , respectively. For faba bean; seed yield, harvest index, plant height, 100-seed weight and No. pods/ plant gave the highest values under irrigation treatment $D$. Results also showed that all characteristics of faba bean were significantly affected by irrigation treatments in both growing seasons.
\end{abstract}

Key words: faba bean irrigation, water consumptive use, water productivity and productivity of water applied.

\section{INTRODUCTION}

Egypt is the solely country worldwide that its agricultural production is under irrigation i.e. irrigated agriculture. Nile River is the main fresh water resources with a fixed allocation to the country. Due to the high annual increasing population, the capita share from water for different purposes becomes less than the water poverty edge and it expecting to decrease to the scarcity level of less than $500 \mathrm{~m}^{3}$ in the few coming decades.
Faba bean is one of the main legume crops growing in winter season in the area of North Nile Delta. This area receive about $150 \mathrm{~mm}$ of rainfall Faba bean contain high percentage of protein. It is useful in increasing the fertility of soils as a result of its capability in fixation of atmospheric nitrogen by root nodules.

Ahmed et al. (2008) reported that shoot fresh weight of faba bean plants grown under drought condition was reduced by $50 \%$ compared with the control plants. French (2009) and Alderfasi (2009) found that low soil moisture content caused an irreversible loss in yield potential.

Abd EL Aziz (2008) had pointed out that treatment which depended on rainfall and supplemental irrigation significantly increased plant height, number of branches, leaf area, number of pods / plant, number of seeds / pod, and weight of 100 seeds. Al- Suhaibani (2009) pointed out that high crude protein and carbohydrate percent of faba bean seeds were associated with low water applied levels.

Alderfasi and Alghamdi (2010) concluded that water stress is well known as one of the most significant factors affecting plant growth, photosynthesis productivity and seed yield and quality for faba bean and most crops. They also reported that shortage of water decreased most growth characters noticed that adequate water supplies up to $70 \%$ of water holding capacity promoted growth and resulted in higher plant height, large number of leaves and branches per plant. This is turn favorably influenced number of pods/plant, 100 - seed weight and consequently seed yield per hectare. They also reported that water supplies up to $100 \%$ of water holding capacity recorded the highest seed yield in both seasons under low rainfall agricultural areas of Saudi Arabia. While water deficit of water supplies up to $75 \%$ of water holding capacity may slightly retard crop growth, this does not restrict the crop,s ability to respond to their high yield.

Balasio et al. (2010) reported that a high water status throughout the growing season is necessary to maintain unimpaired crop growth and high economic yield of faba bean, the imposition of some stress by longer irrigation intervals, higher moisture depletion or skipping irrigation during the early vegetative or during

\footnotetext{
${ }^{1}$ Soils, Water and Environment Research Institute.

Agric. Res. Center, Giza, Egypt.

mona_elmansoury80@yahoo.com

Received October 31, 2016, Accepted December 20, 2016
} 
maturation could still attain similar economic yields as well as saving irrigation water and improving water-use efficiency. They also found that water application efficiency was ranged between $(79 \%)$ and $(62 \%)$ in the first and second season, respectively. Tawadors et al.(1993), Ainer et al. (1994), Khalil (1995) and Ashry et al. (2012) reported that water use efficiency increased by increasing soil moisture stress and it must not be stressed in flowering stage (Tayel and Sabreen, 2011).

Sara, El-Tobgy (2012) stated that the maximum yield of faba bean was produced from traditional irrigation of five irrigations $(1102.71 \mathrm{~kg} / \mathrm{fed}$.) and the minimum yield was obtained under rainfall $(503.86 \mathrm{~kg} /$ fed.). She also reported that the maximum protein percentage $(36.31 \%)$ was produced from rainfall and $26.67 \%$ was recorded with traditional irrigation. AbdelFattah (2014) found that irrigating with $60 \%$ irrigation water calculated based on any of the tested reference evapotranspiration (ETo) methods depending upon the availability of climatic elements is suitable in the studied area. Hence, the main objective of the present study was to find out the effect of conjunction use of rainfall and irrigation water on applied water, water productivity and yield components of faba bean crop.

\section{MATERIALS AND METHODS}

A field trial was carried out during the two faba bean growing seasons 2013/2014 and 2014/2015 at
Sakha Agricultural Research Station. The site is located at middle North of Nile Delta with $30^{\circ}-57^{\prime} \mathrm{N}$ latitude, $31^{\circ}-07^{\prime} \mathrm{E}$ longitude and altitude of about 6 meters above mean sea level. Climatic elements of the area during the two growing seasons are presented in Table (1). The climatic data was recorded by Sakha Agro climatic Station.

Physical and chemical characteristics of the studied site:-

Soil samples from different depths $(0-15 \mathrm{~cm}),(15-$ $30 \mathrm{~cm}),(30-45 \mathrm{~cm})$ and $(45-60 \mathrm{~cm})$ were taken from the studied site. The physical properties of the studied experimental site such as soil field capacity (F.C) and permanent wilting point were determined at the site according to James (1988) and soil bulk density was determined according to Klute, (1986).The soil texture, the particle size distribution was determined according to the International method (Klute, 1986). The obtained results indicated that the soil texture is clay loam as shown in Table 2. Chemical properties such as total soluble salts (soil Ec, dS/ m), soil reaction $(\mathrm{pH})$, both soluble cations and anions were determined according to the methods described by (Jackson, 1973). $\mathrm{So}_{4}{ }^{--}$was calculated by the difference between soluble cations (meq/ L) and anions (meq/ L) as tabulated in Table 3.

Table 1. Climatic elements of; air temperature $\left(T, C^{\circ}\right)$, mean relative humidity $(\mathrm{RH}, \%)$, wind speed $\left(\mathrm{U}_{2}, \mathrm{~m} \cdot \mathrm{sec}^{-1}\right)$, evaporation pan $\left(\mathrm{Ep}, \mathrm{mm}^{-\mathrm{d}^{-1}}\right)$ and rainfall $(\mathrm{Rf}, \mathrm{mm})$

a. $1^{\text {st }}$ season, $2013 / 2014$

\begin{tabular}{|c|c|c|c|c|c|c|c|}
\hline \multirow[t]{2}{*}{ Month } & \multicolumn{3}{|c|}{$\mathbf{T}, \mathbf{C}^{\circ}$} & \multirow{2}{*}{$\begin{array}{c}\text { RH, } \\
\%\end{array}$} & \multirow{2}{*}{$\begin{array}{c}\mathrm{U}_{2}, \\
\text { m.sec }^{-1}\end{array}$} & \multirow{2}{*}{$\begin{array}{r}\text { Ep, } \\
\text { mm.d }^{-1}\end{array}$} & \multirow{2}{*}{$\begin{array}{c}\text { Rf, } \\
\text { mm month }\end{array}$} \\
\hline & Max & Min & Mean & & & & \\
\hline Nov.2013 & 25.39 & 15.14 & 20.27 & 75.72 & 0.80 & 2.28 & 0.00 \\
\hline Dec.2013 & 19.64 & 8.51 & 14.08 & 79.84 & 0.61 & 4.15 & 81.90 \\
\hline Jan.2014 & 20.34 & 7.55 & 13.95 & 80.55 & 0.54 & 1.60 & 20.70 \\
\hline Feb.2014 & 20.64 & 8.19 & 14.42 & 79.53 & 0.79 & 2.52 & 16.50 \\
\hline Mar.2014 & 22.94 & 11.71 & 17.33 & 71.45 & 0.96 & 3.14 & 26.20 \\
\hline Apr.2014 & 27.50 & 15.53 & 21.52 & 65.80 & 1.07 & 4.91 & 20.20 \\
\hline Seasonal & 22.74 & 11.11 & 16.93 & 75.48 & 0.80 & 3.10 & 165.50 \\
\hline \multicolumn{8}{|c|}{$2^{\text {nd }}$ season, $2014 / 2015$} \\
\hline \multirow[t]{2}{*}{ Month } & \multicolumn{3}{|c|}{$\mathbf{T}, \mathbf{C}^{\circ}$} & \multirow{2}{*}{$\begin{array}{c}\text { RH, } \\
\%\end{array}$} & \multirow{2}{*}{$\begin{array}{c}\mathrm{U}_{2} \\
\mathbf{m . s e c} \\
1\end{array}$} & \multirow{2}{*}{$\begin{array}{r}\text { Ep, } \\
\text { mm.d }^{-1}\end{array}$} & \multirow{2}{*}{$\begin{array}{c}\text { Rf, } \\
\text { mm month }\end{array}$} \\
\hline & Max & Min & Mean & & & & \\
\hline Nov.2014 & 24.30 & 13.79 & 19.05 & 74.15 & 0.78 & 2.77 & 24.60 \\
\hline Dec.2014 & 22.27 & 9.72 & 16.00 & 76.05 & 0.53 & 1.72 & 5.70 \\
\hline Jan.2015 & 18.79 & 6.46 & 12.63 & 74.60 & 0.82 & 2.70 & 52.55 \\
\hline Feb.2015 & 19.01 & 7.65 & 13.33 & 74.75 & 0.84 & 2.90 & 38.80 \\
\hline Mar.2015 & 22.69 & 11.69 & 17.19 & 70.59 & 1.01 & 3.23 & 15.25 \\
\hline Apr.2015 & 25.64 & 13.70 & 19.67 & 63.40 & 1.11 & 6.07 & 35.85 \\
\hline Seasonal & 22.12 & 10.50 & 16.31 & 72.26 & 0.85 & 3.23 & 172.75 \\
\hline
\end{tabular}


Table 2. Particle Size Distribution and soil water constants of the studied experimental site

\begin{tabular}{|c|c|c|c|c|c|c|c|c|}
\hline \multirow{2}{*}{$\begin{array}{l}\text { Soil } \\
\text { Depth, cm. }\end{array}$} & \multicolumn{3}{|c|}{ Particle Size Distribution } & \multirow{2}{*}{$\begin{array}{c}\text { Texture } \\
\text { Class }\end{array}$} & \multirow{2}{*}{$\begin{array}{c}\text { F.C } \\
\%\end{array}$} & \multirow{2}{*}{$\begin{array}{c}\text { P.W.P } \\
\%\end{array}$} & \multirow{2}{*}{$\begin{array}{l}\text { AW } \\
(\%)\end{array}$} & \multirow{2}{*}{$\begin{array}{c}\text { Bd, } \\
\mathbf{M g} / \mathbf{m}^{3}\end{array}$} \\
\hline & Sand\% & Silt \% & Clay \% & & & & & \\
\hline $0-15$ & 15.70 & 31.00 & 53.30 & Clay & 44.61 & 26.56 & 18.05 & 1.04 \\
\hline $15-30$ & 22.40 & 33.10 & 44.50 & Clay & 40.20 & 21.44 & 18.76 & 1.09 \\
\hline $30-45$ & 20.70 & 40.30 & 39.00 & Clay loam & 38.70 & 20.60 & 18.10 & 1.11 \\
\hline $45-60$ & 22.90 & 40.90 & 36.20 & Clay loam & 36.30 & 19.83 & 16.47 & 1.16 \\
\hline Mean & 20.43 & 36.33 & 43.25 & Clay loam & 39.95 & 22.11 & 17.85 & 1.10 \\
\hline
\end{tabular}

Where: - F.C $\%=$ Soil field capacity, P.W.P $\%=$ Permanent wilting point, AW \% = Available water, and Bd, $\mathrm{Mg} / \mathrm{m}^{3}=\mathrm{Soil} \mathrm{bulk}$ density.

Table 3. Some chemical properties of the studied experimental site

\begin{tabular}{|c|c|c|c|c|c|c|c|c|c|c|}
\hline \multirow{3}{*}{$\begin{array}{c}\text { Soil } \\
\text { Depth, } \\
\text { Cm }\end{array}$} & \multirow{3}{*}{$\begin{array}{c}\text { Ec, } \\
\mathrm{ds} / \mathrm{m}\end{array}$} & \multirow{3}{*}{$\begin{array}{c}\text { PH } \\
(1: 2.5) \\
\text { soil water } \\
\text { suspension }\end{array}$} & \multicolumn{8}{|c|}{ Soluble ions, meq/l } \\
\hline & & & \multicolumn{4}{|c|}{ Cations } & \multicolumn{4}{|c|}{ Anions } \\
\hline & & & $\mathrm{Ca}^{++}$ & $\mathbf{M g}^{++}$ & $\mathrm{Na}^{+}$ & $\mathbf{K}^{+}$ & $\mathrm{CO}_{3}^{--}$ & $\mathrm{HCO}_{3}^{-}$ & $\mathrm{Cl}^{-}$ & $\mathrm{SO}_{4}{ }^{--}$ \\
\hline $0-15$ & 1.83 & 8.65 & 7.31 & 2.18 & 8.70 & 0.22 & 0.00 & 4.30 & 9.00 & 5.11 \\
\hline $15-30$ & 2.45 & 8.54 & 9.54 & 5.10 & 9.60 & 0.19 & 0.00 & 3.90 & 8.90 & 11.63 \\
\hline $30-45$ & 2.56 & 8.49 & 9.67 & 5.47 & 10.02 & 0.18 & 0.00 & 3.70 & 7.80 & 13.84 \\
\hline $45-60$ & 3.01 & 8.37 & 11.50 & 6.28 & 12.00 & 0.17 & 0.00 & 3.60 & 7.00 & 19.35 \\
\hline Mean & 2.46 & 8.51 & 9.51 & 4.76 & 10.08 & 0.19 & 0.00 & 3.88 & 8.18 & 12.48 \\
\hline
\end{tabular}

\section{Cultural procedures.}

All agricultural practices were implemented as the local farmers done in their fields based on the recommendations of the Agricultural Research Center (ARC) except irrigation treatments. Faba bean Giza 843 variety was cultivated. Sowing date was on 19 Nov. 2013 \& 15 Nov. 2014 and harvesting date in the two growing seasons was on 26 Apr. 2014 \& 24 Apr. 2015 for $1^{\text {st }}$ season and $2^{\text {nd }}$ season.

Irrigation treatments:

Irrigation treatments were as follows:

Treatment A: control treatment (sowing irrigation (S) plus rainfall (Rf)).

Treatment B: given one irrigation following sowing irrigation plus rainfall.

Treatment C: given two irrigations after sowing irrigation plus rainfall.

Treatment D: given three irrigations following sowing irrigation plus rainfall.

Statistical design and analyses:

All statistical analyses were performed with Costat (version 6.3030 and Microsoft Office Excel 2007 programs. The experimental design was a complete randomized design with three replications. Each replication contains 6 furrows with length $30 \mathrm{~m}$ (area, $90 \mathrm{~m}^{2}$ ).

Data collection:

A. Water parameters:

- Irrigation water (IW)

Irrigation water was measured by contracted rectangular weir (Michael, 1978):

$\mathrm{Q}=0.0184(\mathrm{~L}-0.2 \mathrm{H}) \mathrm{H}^{1.5}$

In which
$\mathrm{Q}=$ discharge, litre/second

$\mathrm{L}=$ length of crest, $\mathrm{cm}$

$\mathrm{H}=$ head over the weir, $\mathrm{cm}$.

- Effective rainfall $\left(\mathbf{R f}_{\mathrm{e}}\right)$

Effective rainfall $\left(\mathrm{Rf}_{\mathrm{e}}\right)$ was computed as rainfall multiply by 0.7 (Novica, 1979).

- Water applied (Wa)

Therefore, water applied equaled irrigation water (IW) plus total rainfall ( $\left.\sum \mathrm{Rf}\right)$.

- Consumptive use (CU)

Actual consumptive use (CU) or so-called crop evapotranspiration $\left(\mathrm{ET}_{\mathrm{c}}\right)$ was determined based on soil moisture depletion in the effective root zone of $60 \mathrm{~cm}$ as follows (Hansen et al., 1979):

$$
\mathrm{Cu}=\frac{F C-\theta}{100} * \frac{D b}{D w} \leqslant d
$$

Where:

$\mathrm{CU}=$ consumptive use or actual crop water consumed, $\mathrm{cm}$.

$\mathrm{FC}=$ soil moisture content on weight basis at field capacity

$\Theta=$ soil moisture content on the weight basis before irrigation

$\mathrm{Db}=$ bulk density $\left(\mathrm{kg} \cdot \mathrm{m}^{-3}\right)$

$\mathrm{Dw}=$ density of water $\left(\mathrm{kg} \cdot \mathrm{m}^{-3}\right)$

$\mathrm{d}=$ effective root zone of $60 \mathrm{~cm}$.

It should be notified that soil moisture depletion included the effective rainfall $\mathrm{Rf}_{\mathrm{e}}$ as descript before.

- Crop-water functions

1. Water productivity (WP):

Water productivity as defined by Boss (1980) is the parameter of crop-water functions which reflects the 
capability of crop water consumed in producing marketable yield as follows:

$\mathrm{WP}=\mathrm{Y} / \mathrm{CU}$

Where:

$\mathrm{WP}=$ water productivity $\left(\mathrm{kg} \cdot \mathrm{m}^{-3}\right.$ water consumed $)$

$\mathrm{Y}=$ marketable yield $(\mathrm{kg})$

$\mathrm{CU}=$ crop-water consumption $\left(\mathrm{m}^{3}\right)$.

2. Productivity of water applied (PWa, $\mathrm{kg} \mathrm{m}^{-3}$ ):

Productivity of water applied (PWa) was calculated according to Ali et al. (2007).

$\mathrm{PWa}=\mathrm{Y} / \mathrm{Wa}$

Where:

PWa $=$ productivity of water applied $\left(\mathrm{kg} / \mathrm{m}^{3}\right)$

$\mathrm{Y}=$ yield $\left(\mathrm{kg} \mathrm{fed}^{-1}\right)$ and

$\mathrm{Wa}=$ water applied $\left(\mathrm{m}^{3} . \mathrm{fed}^{-1}\right)$.

B. Vegetative, yield and yield components:

1- Plant height end of the season. 2-100 seed weight.

3- Biological yield.

5- Straw yield. 4- Seed yield.

7- Number of pods/ plant.

Harvest index $=($ Seed yield $/$ Biological yield $)$

\section{RESULTS AND DISCUSSION}

\section{A -Water parameters}

\section{Effective rainfall $\left(\mathbf{R f}_{\mathrm{e}}\right)$}

Values of seasonal rainfall as tabulated in Table (4) and illustrated in Fig (1) cleared out that rainfall in the studied area are from November through April. Meaningfully, rainfall is distributed among the faba bean growing season. This situation is considering rainfall as a main component of water applied to such winter crop of faba bean. Mean values of rainfall can be arranged in descending order as 43.80, 36.63, 28.03, 27.65, 20.73 and $12.30 \mathrm{~mm}$ for December, January, April, February, March and November, respectively. In general, seasonal rainfall is in average of $169.13 \mathrm{~mm}$ or $710.35 \mathrm{~m}^{3} /$ fed which is fairly meet some winter crops, water needs.

Therefore, in this direction effective rainfall $\left(\mathrm{Rf}_{\mathrm{e}}\right)$ or the useful portion of rainfall used in crop water consumption which equaled rainfall multiply by 0.7 took the same trend as total rainfall (Novica, 1979).

This fact is explained by Allen (1991) who pointed out that not all rainfall is effective in fulfilling irrigation water requirements. Reasons include:

1. Surface runoff due to high rainfall intensity, low infiltration rates or frozen soil.

2. Deep percolation from heavy rainfall occurring immediately following an irrigation or previous rainfall event.

3. Evaporation of intercepted rain on plant leaves.

\section{Water applied (Wa)}

Values of seasonal water applied (Wa) which consists of the two components of irrigation water (IW) and total rainfall (Rf) are presented in Table (4) and Fig (1) illustrated that $\mathrm{Wa}$ has the same trend with number of irrigations, the high number of irrigations the high amount of water applied. The mean contribution percentages of rainfall to water applied (Wa) are 55.8, $47.3,40.7$ and $36.4 \%$ for treatments A, B, C, and D, respectively. This main finding is useful regarding two principal remarks of partially fulfill crop water needs from one side and decreasing the amount of irrigation water applied from the other side, particularly under the water shortage facing Egypt.

Comparing traditional irrigation (treatment D) with other irrigation treatments, average percentages of water saving in the two growing seasons are 34.8, 23.0 and $10.6 \%$ for treatments $\mathrm{A}, \mathrm{B}$ and $\mathrm{C}$, respectively.

The obtained result is in harmony with that obtained with Alderfasi and Alghamdi (2010) who stated that irrigation water has the same direction with number of watering events.

\section{Water consumptive use $(C U)$ :}

The amount of crop water consumptive use (CU) represents the useful portion of water applied in growing the cultivated crops and ultimately in crop production. The seasonal amounts of $\mathrm{CU}$ with its rate are tabulated in Table (5) and Fig. (2). Increasing number of irrigations are resulted in increasing $\mathrm{CU}$ with its rate. Average rate of $\mathrm{CU}$ could be arranged in descending order as; 2.8, 2.4, 2.1 and $1.8 \mathrm{~mm}_{\text {day }}{ }^{-1}$ for treatments D, C, B and A, respectively. The obtained results are emphasized the fact that enough soil moisture content which resulted from increasing irrigation numbers are reflected in high $\mathrm{CU}$ and its rate. This finding is in the same line with that obtained with Balasio et al. (2010) and Alderfasi and Alghamdi (2010).

\section{Crop - water functions}

In general, crop - water functions or so-called the productivity of unit water either consumed or applied. In this regard, water productivity (WP) reflects the capability of each unit of consumed water in the crop productivity. While the productivity of water applied (PWa) reflects the capability of each unit of applied water in crop production. Both parameters are depending upon the obtained yield as a nominator and water either consumed $(\mathrm{Cu})$ or water applied $(\mathrm{Wa})$ as dominator.

Mean values of WP and PWa as presented in Table (6) and illustrated in Figs (3 and 4) cleared out that the mean values of WP can be arranged in descending order 
as; $1.23,1.11,1.04$ and $1.00 \mathrm{~kg} \mathrm{~m}^{-3}$ for treatments $\mathrm{B}, \mathrm{C}$ ,A and $\mathrm{D}$, respectively.

The corresponding values for PWa are; 1.12, 1.01, 1.00 and $0.95 \mathrm{~kg} \mathrm{~m}^{-3}$. The obtained result is in harmony with that obtained with Tawadors et al.(1993), Ainer et al. (1994), Khalil (1995) and Ashry et al. (2012) reported that water use efficiency increased by increasing soil moisture stress.

Table 4. Seasonal water applied (Wa); irrigation water (IW) and total rainfall (RF) as effected by irrigation treatments for faba bean

\begin{tabular}{|c|c|c|c|c|}
\hline $\begin{array}{l}\text { Treatment } \\
\text { Parameters }\end{array}$ & $\begin{array}{c}\text { A (control) } \\
\mathbf{S}+\mathbf{R f}\end{array}$ & $\begin{array}{c}\text { B } \\
\mathbf{S}+\mathbf{1} \text { Irr. }+ \text { Rf }\end{array}$ & $\begin{array}{c}\mathrm{C} \\
\mathrm{S}+2 \text { Irr. }+ \text { Rf }\end{array}$ & $\begin{array}{l}\text { D (traditional) } \\
\text { S + 3 Irr. + Rf }\end{array}$ \\
\hline \multicolumn{5}{|c|}{ Season 2013/2014 } \\
\hline Wa, $\mathrm{m}^{3}$ fed $^{-1}$. & 1289.6 & 1513.3 & 1777.5 & 1901.5 \\
\hline $\mathrm{Wa}, \mathrm{mm}$. & 307 & 360 & 423 & 453 \\
\hline I.W., $\mathrm{m}^{3}$ fed $^{-1}$. & 594.5 & 818.2 & 1082.4 & 1206.4 \\
\hline I.W., mm. & 143 & 195 & 258 & 287 \\
\hline $\mathrm{Rf}, \mathrm{m}^{3} \mathrm{fed}^{-1}$ & \multicolumn{4}{|c|}{695.1} \\
\hline $\mathrm{Rf}, \mathrm{mm}$. & \multicolumn{4}{|c|}{166} \\
\hline \multicolumn{5}{|c|}{ Season 2014/2015 } \\
\hline Wa, $\mathrm{m}^{3}$ fed $^{-1}$. & 1257.3 & 1493.3 & 1713.3 & 2002.4 \\
\hline Wa, mm. & 299 & 356 & 408 & 477 \\
\hline I.W., $\mathrm{m}^{3} \mathrm{fed}^{-1}$. & 531.7 & 767.7 & 987.7 & 1276.8 \\
\hline I.W., mm. & 127 & 183 & 235 & 304 \\
\hline $\mathrm{Rf}, \mathrm{m}^{3} \mathrm{fed}^{-1}$ & & & & \\
\hline $\mathrm{Rf}, \mathrm{mm}$. & & & & \\
\hline \multicolumn{5}{|c|}{ Mean of the two seasons } \\
\hline Wa, $\mathrm{m}^{3} \mathrm{fed}^{-1}$. & 1273.5 & 1503.4 & 1745.5 & 1952.0 \\
\hline $\mathrm{Wa}, \mathrm{mm}$ & 303 & 358 & 416 & 465 \\
\hline I.W., $\mathrm{m}^{3} \mathrm{fed}^{-1}$. & 563.1 & 793.0 & 1035.1 & 1241.6 \\
\hline I.W., mm. & 125 & 189 & 246 & 296 \\
\hline $\mathrm{Rf}, \mathrm{m}^{3} \mathrm{fed}^{-1}$ & \multicolumn{4}{|c|}{710.4} \\
\hline $\mathrm{Rf}, \mathrm{mm}$ & \multicolumn{4}{|c|}{169} \\
\hline
\end{tabular}

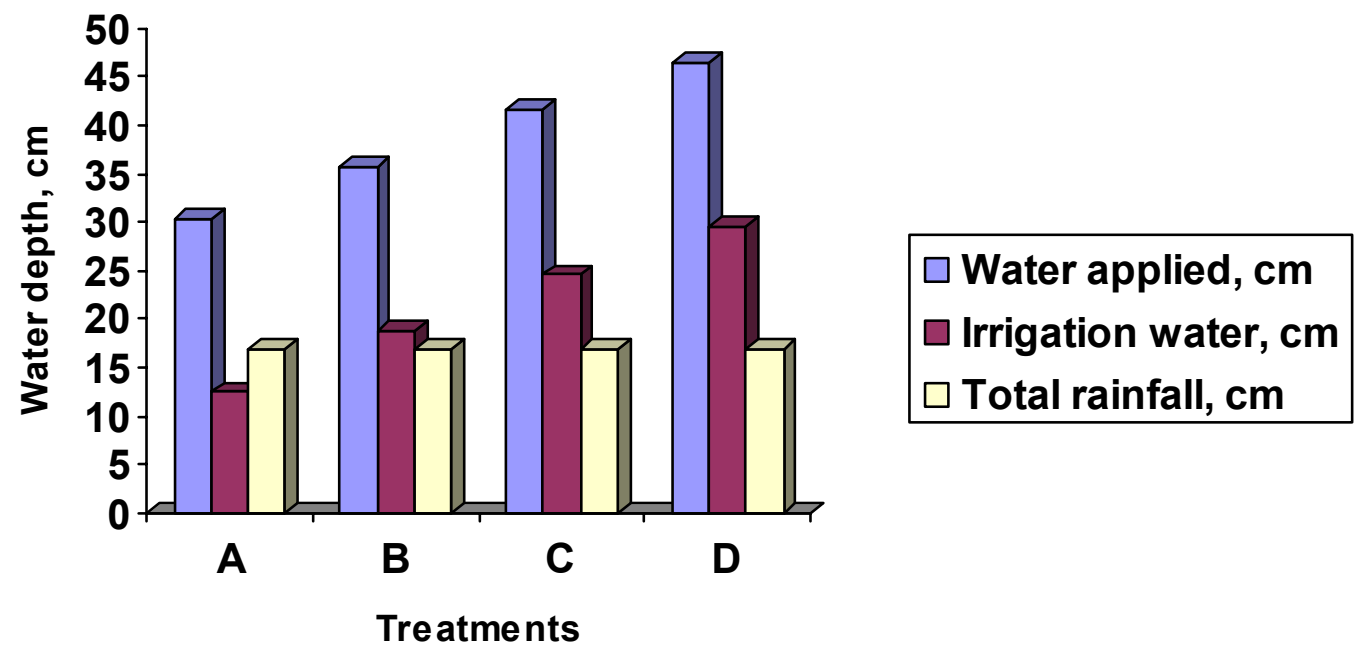

Fig. 1. Mean of the two season for water applied $(\mathrm{cm})$; irrigation water and rainfall as affected by irrigation treatments for faba bean 
Table 5. Seasonal water consumptive use (CU) for faba bean as effected by irrigation treatments in the two growing seasons

\begin{tabular}{|c|c|c|c|c|c|c|c|c|c|}
\hline \multirow{3}{*}{ Treatment } & \multicolumn{3}{|c|}{$1^{\text {st }}$ season } & \multicolumn{3}{|c|}{$2^{\text {nd }}$ season } & \multicolumn{3}{|c|}{ Mean } \\
\hline & \multicolumn{2}{|c|}{$\mathbf{C U}$} & \multirow{2}{*}{$\begin{array}{c}\text { Rate } \\
\text { mm day }^{-1}\end{array}$} & \multicolumn{2}{|c|}{$\mathbf{C U}$} & \multirow{2}{*}{$\begin{array}{c}\text { Rate } \\
\text { mm day }^{-1} \\
\end{array}$} & \multicolumn{2}{|c|}{ CU } & \multirow{2}{*}{$\begin{array}{c}\text { Rate } \\
\text { mm day }^{-1}\end{array}$} \\
\hline & $\mathrm{m}^{3}$ fed $^{-1}$. & $\mathbf{m m}$ & & $\mathrm{m}^{3} \mathrm{fed}^{-1}$ & $\mathbf{m m}$ & & $\mathrm{m}^{3}$ fed $^{-1}$. & $\mathbf{m m}$ & \\
\hline A & 1215.4 & 289 & 1.8 & 1227.4 & 292 & 1.8 & 1221.4 & 291 & 1.8 \\
\hline B & 1352.1 & 322 & 2.0 & 1399.7 & 333 & 2.1 & 1375.9 & 328 & 2.1 \\
\hline $\mathrm{C}$ & 1542.6 & 367 & 2.3 & 1651.8 & 393 & 2.5 & 1597.2 & 380 & 2.4 \\
\hline $\mathrm{D}$ & 1792.7 & 427 & 2.7 & 1919.0 & 457 & 2.9 & 1855.9 & 442 & 2.8 \\
\hline Mean & 1475.7 & 351 & 2.2 & 1549.5 & 369 & 2.3 & 1512.6 & 360 & 2.3 \\
\hline
\end{tabular}

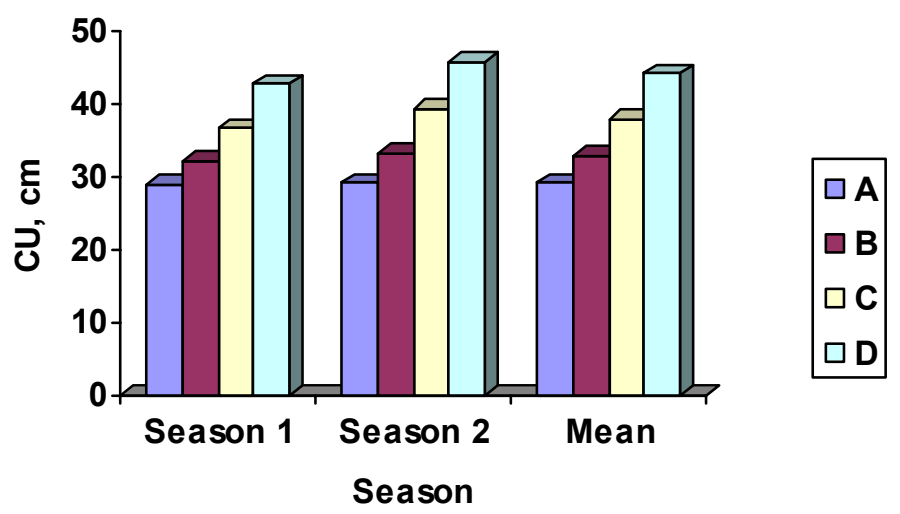

Fig. 2. Seasonal water consumptive use $(\mathrm{cm})$ for faba bean as effected by irrigation treatments in the two growing seasons

Table 6. Water productivity (WP) and productivity of water applied (PWa) for faba bean

\begin{tabular}{|c|c|c|c|c|c|c|}
\hline \multirow{2}{*}{$\overbrace{\text { Treatment }}^{\text {Season }}$} & \multicolumn{2}{|c|}{$\mathbf{1}^{\text {st }}$ growing season } & \multicolumn{2}{|c|}{$2^{\text {nd }}$ growing season } & \multicolumn{2}{|c|}{ Means of the two growing seasons } \\
\hline & $\begin{array}{l}\text { WP, } \\
\mathrm{kg} \mathrm{m}^{-3}\end{array}$ & $\begin{array}{l}\text { PWa, } \\
\mathrm{kg} \mathrm{m}^{-3}\end{array}$ & $\begin{array}{c}\text { WP, } \\
\mathrm{kg} \mathrm{m}^{-3}\end{array}$ & $\begin{array}{l}\text { PWa, } \\
\text { kg m }^{-3}\end{array}$ & $\begin{array}{c}\mathrm{WP} \\
\mathrm{kg} \mathrm{m}^{-3} \\
\end{array}$ & $\begin{array}{c}\text { PWa, } \\
\mathrm{kg} \mathrm{m}^{-3} \\
\end{array}$ \\
\hline A & 1.08 & 1.02 & 0.99 & 0.97 & 1.04 & 1.00 \\
\hline B & 1.29 & 1.15 & 1.17 & 1.09 & 1.23 & 1.12 \\
\hline $\mathrm{C}$ & 1.18 & 1.02 & 1.03 & 1.00 & 1.11 & 1.01 \\
\hline $\mathrm{D}$ & 1.04 & 0.98 & 0.95 & 0.91 & 1.00 & 0.95 \\
\hline & 1.15 & 1.04 & 1.04 & 0.99 & 1.10 & 1.02 \\
\hline
\end{tabular}

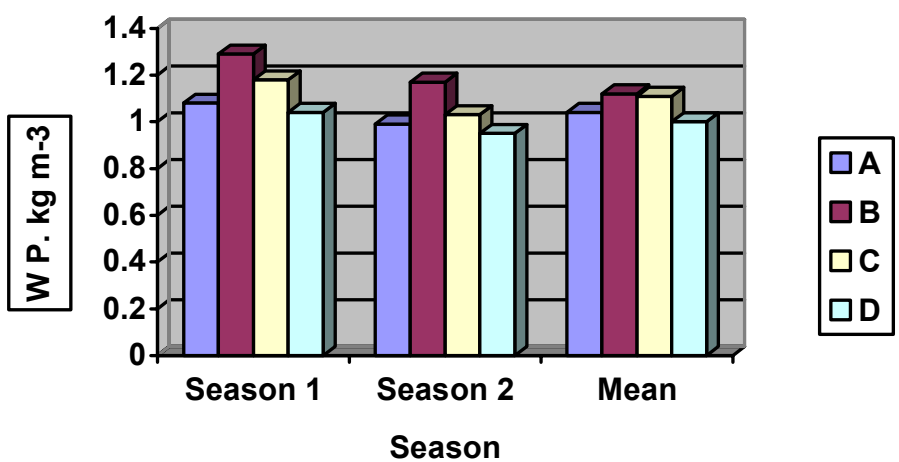

Fig. 3. Effect of irrigation treatments on water productivity (WP) for faba bean 


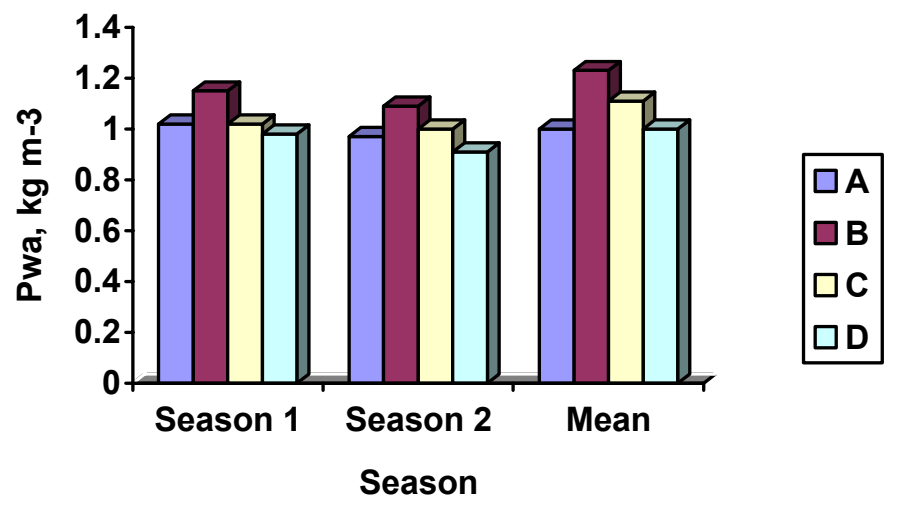

\section{Fig. 4. Effect of irrigation treatments on productivity of water applied (PWa) for faba bean}

\section{B- Effect of irrigation treatments on yield and yield attributes for faba bean crop:}

Presented data in Table 7 (a) and illustrated in Fig. (4) show that irrigation treatments resulted in high significant effect on seed yield in the two growing seasons. Concerning the effect of irrigation treatments, the highest values $1843.8 \mathrm{~kg} \mathrm{fed}^{-1}$ obtained with 3 irrigations after sowing (treatment D). While, the lowest values was $1266.9 \mathrm{~kg} \mathrm{fed}^{-1}$ recorded under rainfall treatment. Generally, increasing the values of seed yield with increasing number of irrigations was due to the sufficient available soil moisture in the root zone. In average, irrigation treatments resulted in decreasing seed yield by $31.3,8.4$ and $4.6 \%$ for treatments A, B and $\mathrm{C}$ respectively comparing with the highest seed yield $100 \%$ obtained from treatment D. These results are in the same trend of those obtained by French (2009), Alderfasi (2009) they found that low soil moisture content caused an irreversible loss in yield potential. Also, Tayel and Sabreen (2011) they stated that faba bean must not be stressed in flowering stage. The results in Table 7 (b) and illustrated in Fig. (5) show that plant height was high significantly affected with irrigation treatments. Comparing the traditional irrigation (treatment D) with other irrigation treatments resulted in decreasing plant height with 4.6, 8.6 and $23.2 \%$ for treatments C, B and A, respectively. These results are in a good agreement with those obtained by Abd EL Aziz (2008).

The same Table (7b) showed that 100 -seed weight and number of pods/ plant were high significantly affected with irrigation treatments. Comparing the traditional irrigation (treatment D) with other irrigation treatments resulted in decreasing 9.0, 10.9 and $16.6 \%$ for treatments C, B and A respectively for 100 -seed weight. While, number of pods/ plant decreased by $15.4,27.3$ and $39.6 \%$ with the same treatments, respectively.The obtained result is in harmony with that obtained with Abd EL Aziz (2008) and Sara, El-Tobgy (2012).

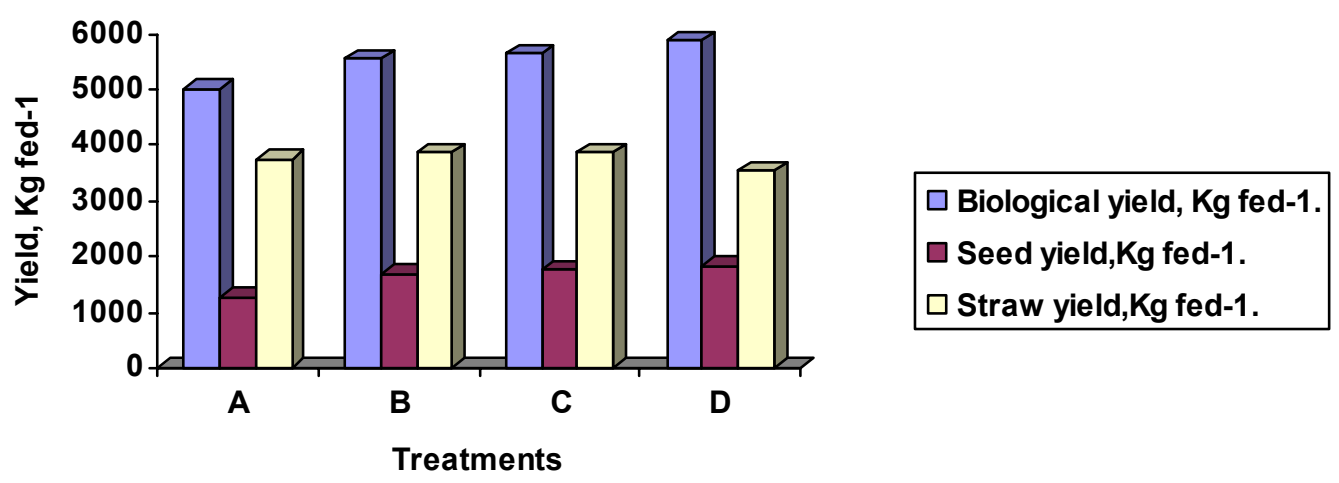

Fig. 5. Mean of faba bean yield as affected with irrigation treatments. 


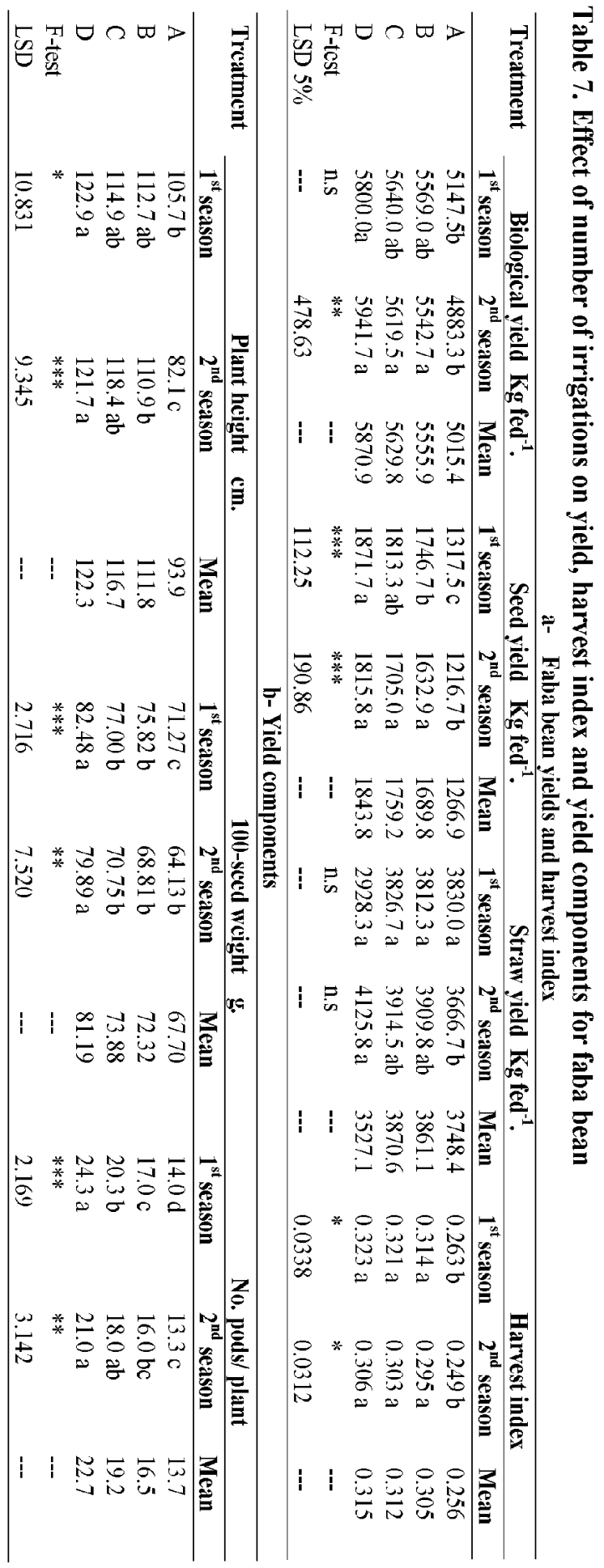




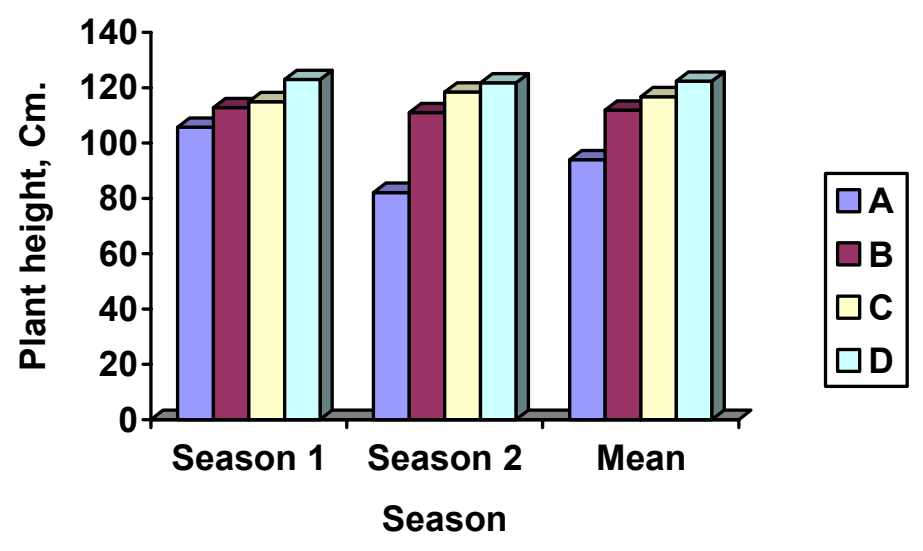

Fig. 6. Effect of irrigation treatments on plant height $(\mathrm{cm})$ for faba bean

\section{CONCLUSION}

The conjunctive use of rainfall with irrigation in North Nile Delta is an effective way in rationalization of irrigating faba bean crop. Given only sowing irrigation (rainfall treatment) produced about $70 \%$ from the maximum yield of the traditional watering which received three irrigations after sowing (treatment D), two advantages could be achieved comparing to the traditional treatment:

- Water saving of $10.6 \%$ which amounted with 206.5 $\mathrm{m}^{3} / \mathrm{fed}^{-1}$ or $496 \mathrm{~m}^{3} / \mathrm{ha}^{-1}$.

- Nearly $90 \%$ from the maximum yield could be obtained.

Therefore, in case of enough water availability, it could be irrigated with faba bean two or three irrigation events watering following sowing. On the other hand, under less water availability or water shortage status, rainfall treatment of sowing irrigation plus rainfall (treatment A) could be implemented. This water regime produced about $70 \%$ of the maximum yield of traditional irrigation of 3 watering (treatment $\mathrm{D}$ ). More investigations should be carried out regarding the contribution conjunction use of rainfall and irrigation in the studied area for water needs of winter crops such as wheat and barley.

\section{REFERENCES}

Abd El-Aziz, M. 2008. Effects of supplementary irrigation on growth and yield components of faba beans (A). Tishreen University. Journal for Research and Scientific StudiesBiological Sci. Series. 30(3): 9-22.

Abdel-Fattah, I.M. 2014. Effective on-farm irrigation management for faba bean crop under current and future climate change conditions. ph. D. thesis, Agric. Soils, Mansoura University.
Ahmed, A. Khalafallah, K. M. Tawfik, Zinab, A. Abd ElGawad. 2008. Tolerance of seven faba bean varieties to drought and salt stresses. Res. J. Agric. And Biolo. Sci. 4(2): 175-186.

Ainer, N.G., W. I.Miseha and H. H. Abdel. Maksoud. 1994. Water management for faba bean in the Delta. Zagazig J. Agric. Res. 20(6):2045-2053.

Ali, M.H., M.R. Hoque. A.A. Hassan and A.khair 2007. Effects of deficit irrigation on yield, water productivity and economic returns of wheat. Agricultural water management, 92 (3): 151-161.

Alderfasi, A. A. 2009. Integrated use of potassium fertilizer and water schedules on growth and yield of two wheat genotypes under Arid Environ. Saudi Arabia. I) Effect on yield and yield component characters. World J. Agric. Sci., 5(2): 221-227.

Alderfasi, A. A. and S. S. Alghamdi.2010. Integrated water supply with nutrient requirements on growth, photosynthesis productivity, chemical status and seed yield of faba bean. American- Eurasian J. Agron, 3(1): 0817.

Allen, R. G. 1991. Irrigation Engineering principles. Utah State Univ.

Al- Suhaibani, N. A. 2009. Influence of early water deficit on seed yield and quality of faba bean under arid environment of Saudi Arabia. American- Eurasian J. Agric. Environ. Sci., 5(5): 649-654.

Ashry, M. R. K, F.R.M Farrag, S.M.M. Abdou and M.E.I. ElAkram. 2012. Rationalization of irrigation water use for faba bean (Vicia faba L.) Fayoum J. Agric. Res. \& Dev., Vol. 26 (1): 26-37.

Balasio, E. D., A. Husseinand M.A. Ahmed. 2010. Effect of watering regimes at two stage of growth on faba bean grain yield at Selaim Basin. Sudan J. Agric. Res. 16:4354.

Bos, M.G. 1980. Irrigation efficiencies at crop production level. ICID. Bulletin 29, 2: 189-260 New Delhi. 
French, R. J. 2009. Effect of early water deficit on growth and development of faba bean. Proceedings of Australian Agronomy Conference, Australian Society of Agronomy., 54: 463-471.

Hansen, V., W. Israelsen and Q.E. Stringharm 1979. Irrigation principles and practices, $4^{\text {th }}$ (ed.), John Willey and Sons, New York.

Jackson, M. 1. 1973. Soil Chemical Analysis. prentice Hall of India private, LTD New Delhi.

James, L. G. 1988. Principles of farm irrigation system design. John Willey and Sons Inc., New York, 543.

Khalil, F.A.F. 1995. Scheduling irrigation of faba bean using the evaporation pan method. M. Sc. Thesis, Fac. Agric., Zagazig Univ., Egypt.

Klute, A.C 1986. Water retention: laboratory Methods. In: A. koute (ed.), Methods of Soil Analysis, part 1-2 (ed.) Agronomy Monogr.9, ASA, Madison, W1 U.S.A, pp. 635 -660 .
Michael, A. M. 1978. Irrigation - Theory and practices. Vikas Publishing House, New Delhi.

Novica, V. 1979. Irrigation of agriculture crops. Fac. Agric. Press, Novi Sad Yugoslavia.

Sara, M. M. El-tobgy 2012. Effective management of faba bean watering under different irrigation levels. M. Sci. thesis, Fac. Agric., Mansoura Univ., Egypt.

Tawadros, H.W., W.I. Miseha , M.F. Wahbaand, B.H. Nageib. 1993. Effect of withholding irrigation at different stages of plant growth on faba bean. Egypt. J. Appl. Sci. 8(8):123-141.

Tayel, M.Y. and Sabreen, Kh. P. 2011. Effect of irrigation regimes and phosphorus level on two vicia faba varieties. III- irrigation water price. The $18^{\text {th. }}$ Annual Conference of the Misr Soc. Ag. Eng., 26-27 October, 2011. Misr. J. of Agric. Eng. 28(4): 603-618. 


\section{الملغص العري \\ تأثير الرى المتبلال عل الحتياجلت المائية ولاننتاجية المائية لمحصط الفرل البلدى}

من عبد الحليم المنصورى

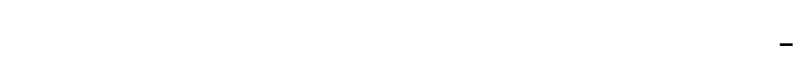

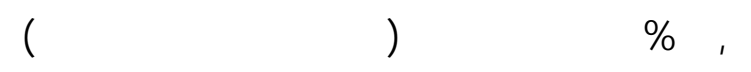

\% \% ب بالنبة للمعاملة أ (المطرية).

- اعلاء ريتين بعد الزراعة (المعلملة ج) أعطت ققربيآ ف س محصول المعاملة د (س ريك بعد الزراعة) مع توفير رية. - أعلى متونط لفيم لنتلجية المية (WP) وانتلجية المية المضلفة (PWa)

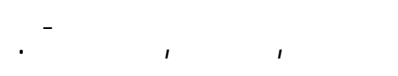

- من النتائج أيضا وجود معنوية فى مغم صفل المح صول تنيجة لتأثيرمعلملات الرى فى الموسمين فى الصفلت التالية

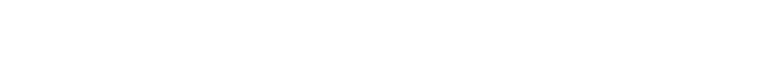

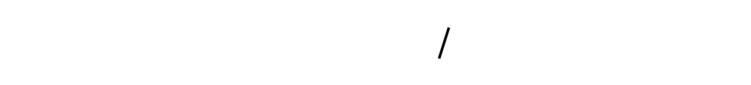
نتجت من معاملة الرى د. وعليه: - توص الدرلسة بلمكلنية الإنقاةة من مي لمة الأطط ارف مى

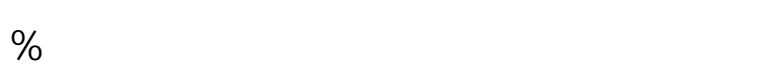
من المحصول الأعلى.

- يمكن رى الفول البلدى بشمل الدلتا ريتين فق ط بع د ري ــة

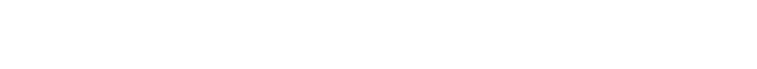
فس المحصول ووفر رية وذك فى حالة ندرةميلة الرى.
أليمت تجربة حقلية بمكة البحوث الزراعية بسخا بمحلظة

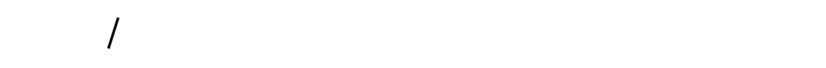

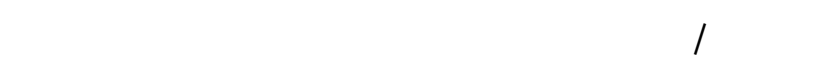

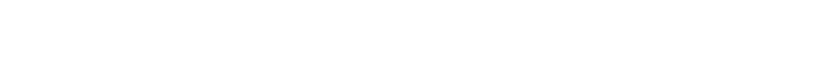
العلافلت المائية للفول البلدى.

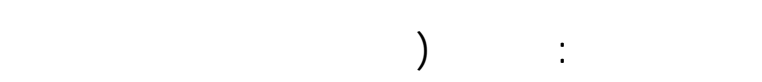

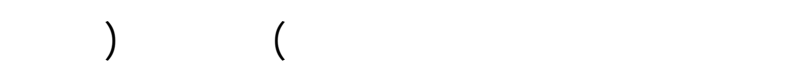

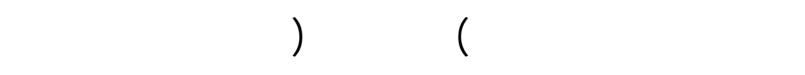

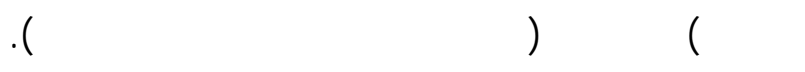
والصف المنزرع جيزة سعی والتصميم الحصائى الم ستخدم قاعلت كلملة العثولئية فى ثلاث مكررات. له النبائج المتحطل علها:

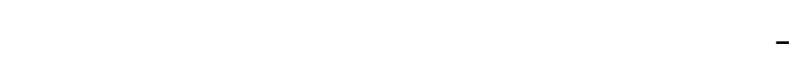

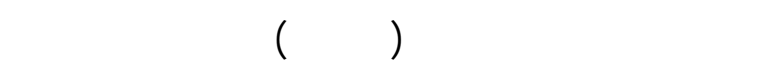

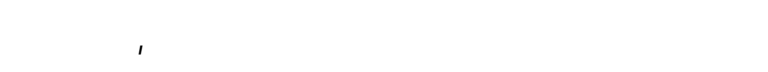

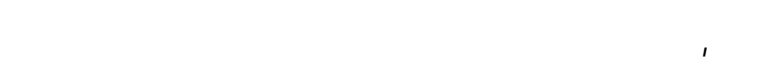
التوله. 